\title{
The application of Standardized Precipitation Index (SPI) to monitor drought in surface and groundwaters
}

\author{
Justyna Kubicz ${ }^{1, *}$ \\ ${ }^{1}$ Wroclaw University of Environmental and Life Sciences, Institute of Environmental Engineering, \\ 24 Grunwaldzki Sq., 50-363 Wroclaw, Poland
}

\begin{abstract}
The paper presents the initial studies with the aim to assess the possibility to apply of Standardized Precipitation Index SPI to monitor drought in surface and groundwaters. The fact that data about precipitation are highly available allows for precise monitoring of the periods of occurrence and intensification of meteorological drought by determining the standardized SPI index. The evaluation of current water deficits in surface water courses and groundwaters is very difficult due to the fact that the measurement network is relatively scarce. In order to apply SPI to monitor hydrological and hydrogeological drought, it is required to assess the significance and level of the correlation between drought indices in the test area and then to calculate the probability of correct determination of drought in surface and groundwaters with use of SPI.
\end{abstract}

\section{Introduction}

Monitoring droughts and the ability to predict them is an essential issue, in particular due to the fact that the number of extreme situations, such as droughts, in the natural environment has increased recently. At the same time, it is noted that the periods of drought are becoming longer and the intensity of droughts increases [1-3]. However, literature on droughts is relatively scarce, in comparison to publications on floods. This is probably due to the nature of sudden surges and floods, which are much more spectacular then drought [4]. Droughts progress slowly and their effects are less visible. Unfortunately, they are no less expensive for the economy and society than floods $[4,5]$.

One of the indices that are most commonly used to monitor meteorological drought is the SPI (Standardised Precipitation Index), developed by McKee [6]. It was the model for creating other standardised drought indices, such as the SWI (Standardised Water Level Index) [7, 8] used in this study and the SGI (Standardised Groundwater Level Index) $[9,10]$.

In Poland, meteorological and hydrological conditions are monitored by the Institute of Meteorology and Water Management under the State Environment Monitoring Program, while the current hydrogeological conditions are monitored by the Polish Hydrogeological Survey, also under the State Environment Monitoring Program. Additionally, the National

${ }^{*}$ Corresponding author: justyna.kubicz@upwr.edu.pl 
Water Management Authority operates the project "Development of drought effects prevention management in river basins". Its main objective is to propose mitigation and prevention actions in order to reduce the negative influence of droughts on the society, environment and economy [11]. An indirect outcome of the project is the development of a set of documents that present the historical instances of drought in Poland and identify areas that are particularly susceptible to the occurrence and effects of drought $[12,13]$.

The paper presents the initial studies with the aim to assess the possibility to apply of Standardized Precipitation Index SPI to monitor drought in surface and groundwaters. The fact that data about precipitation are highly available allows for precise monitoring of the periods of occurrence and intensification of meteorological drought by determining the standardized SPI index. The evaluation of current water deficits in surface water courses and groundwaters is very difficult due to the fact that the measurement network is relatively scarce. The analyses were based on the assumption that there is an existing correlation between the SPI, SWI and SGI indices, which enables the evaluation of hydrological and hydrogeological drought based on the meteorological drought index SPI. The Author decided to present the issue based on examples from three observation points located in one catchment. She has identified a research problem and proposed a test methodology that may be used in other areas.

\section{Data and methodology of the tests}

Calculations were based on precipitation data and measurements of groundwater level in the village Polanów as well as data on water level in the Grabowa river at the Krąg observation site (Fig. 1).Data were obtained from databases of the Institute of Meteorology and Water Management - National Research Institute and Polish Geological Institute - National Research Institute. The analysis covered information from the years 1980-2013. In terms of administration, the observation sites were located in the Western Pomeranian Voivodeship. According to the division into physical and geographical regions by Kondracki [14] it is the area of the West Pomeranian Lake District and the Wysoczyzna Polanowska. The water level in the Grabowa river was measured on $41.9 \mathrm{~km}$ of the river (MPHP 2010). The basic characteristics of the water course at that observation site were as follows: $\mathrm{NNQ}=0.75 \mathrm{~m}^{3} \cdot \mathrm{s}^{-1}, \mathrm{SNQ}=1.96 \mathrm{~m}^{3} \cdot \mathrm{s}^{-1}, \mathrm{SSQ}=2.78 \mathrm{~m}^{3} \cdot \mathrm{s}^{-1}, \mathrm{SWQ}=6.55 \mathrm{~m}^{3} \cdot \mathrm{s}^{-1}$, $\mathrm{WWQ}=14.2 \mathrm{~m}^{3} \cdot \mathrm{s}^{-1}[15]$. Measurements of groundwater level were taken in quaternary gravel sediments. The bottom of the aquifier was at the depth of $24 \mathrm{~m}$ below ground level, while the water level stabilised at the depth of $13.25 \mathrm{~m}$ below ground level. The values of water level in the river and the groundwater level in the context of precipitation are presented in Fig. 2. Basic statistics of the data used are listed in Table 1.

Table 1. Statistics of measurements data.

\begin{tabular}{|c|c|c|c|c|c|c|}
\hline & Site & Mean & Median & Maximum & Minimum & $\begin{array}{c}\text { Standard } \\
\text { deviation }\end{array}$ \\
\hline Precipitation (mm) & Polanów & 70.58 & 63.15 & 231.40 & 1.50 & 40.36 \\
\hline Water level (cm) & Krąg & 117.80 & 117.61 & 146.26 & 86.26 & 7.51 \\
\hline $\begin{array}{c}\text { Groundwater level } \\
\text { (m p.p.t.) }\end{array}$ & Polanów & 13.05 & 13.03 & 12.43 & 13.55 & 0.21 \\
\hline
\end{tabular}




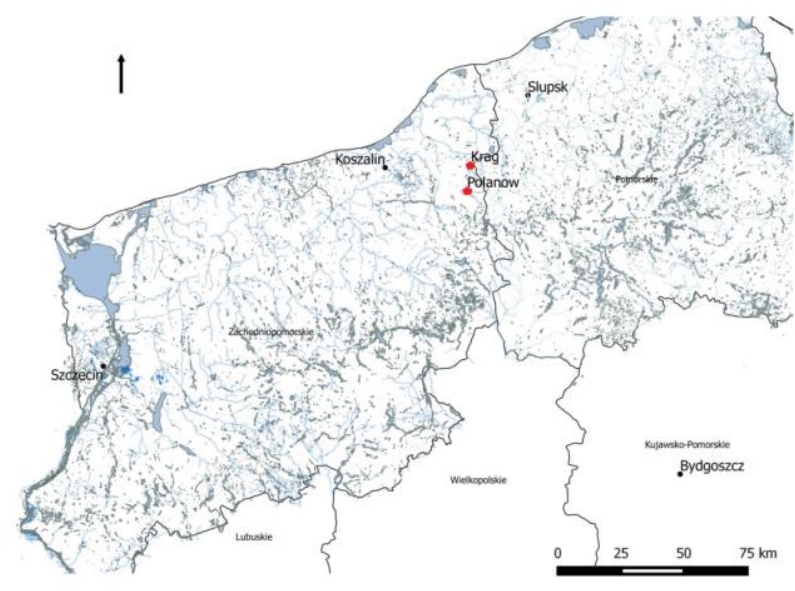

Fig. 1. Localization of measurement points.

a)
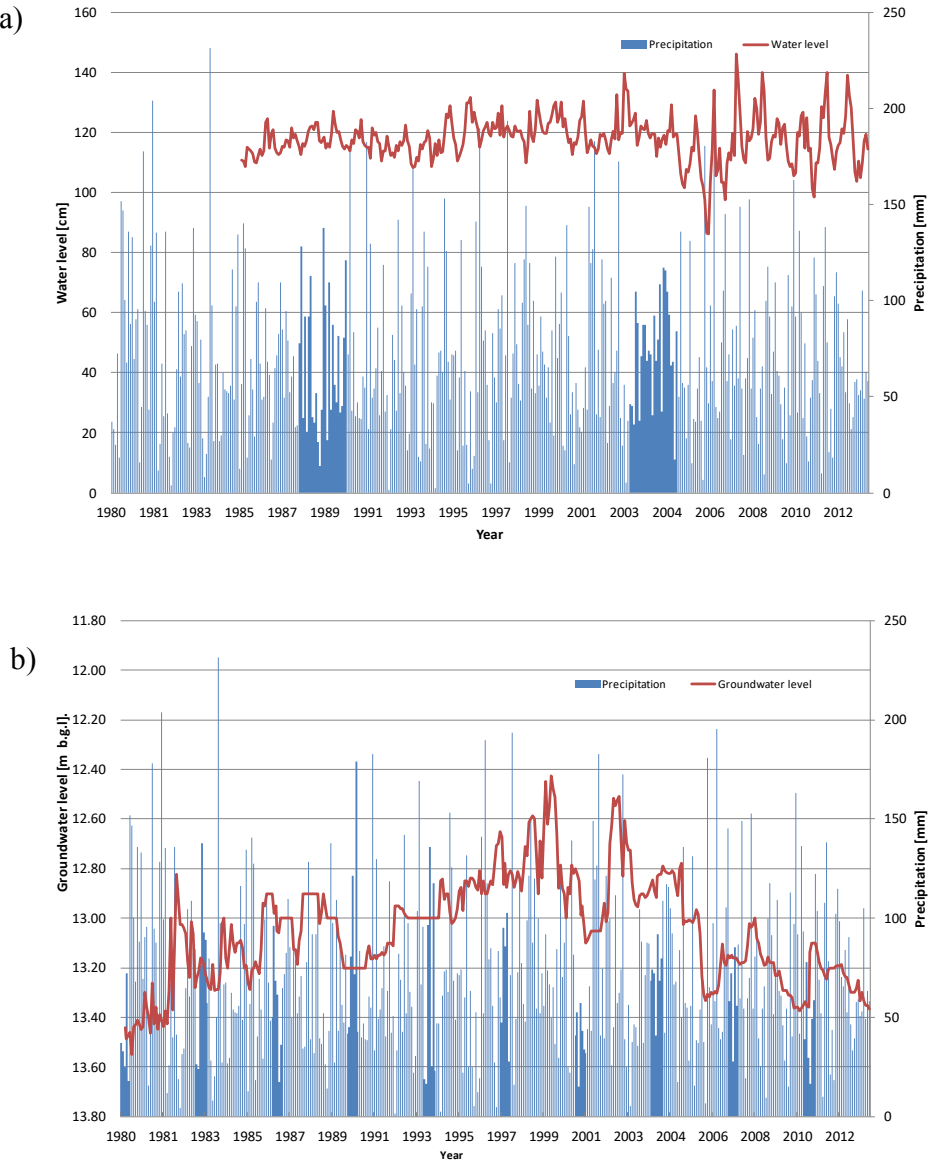

Fig. 2. Histograms showing surface water level (a) and groundwater level (b) hydrographs with corresponding precipitation. 
The Standardised Precipitation Index (SPI) was developed for quantitative evaluation of precipitation deficit in various time scales that reflect the influence of drought on the availability of water resources. It is determined for long-term precipitation series. Positive SPI values refer to precipitation above the median, while negative ones to precipitation below the median $[6,16,17]$. The SPI classification system developed by McKee is used to define the intensity of drought periods for various time scales. In Poland, the use of classification by Łabędzki is recommended [16].

SPI for 1-6 month periods (SPI-1, SPI-2, SPI-3, SPI-6) is used to monitor short-term or seasonal precipitation excess or deficits, while SPI calculated for 12-month period (SPI-12) for medium-term (months), and SPI for 24 months (SPI-24) - long-term ones. According to literature, 2-3 months' SPI has a good correlation with soil moisture content. It may indicate soil and agricultural drought or excessive moisture content in soil. The 6-12 month SPI correlates with flow intensity in rivers and points to the risk of hydrological drought in surface waters, while SPI for 24 months and more is suitable for the detection of droughts that cause long-term effects (such as groundwater drought) [17].

The SPI index has been used since 2000 by the team led by Łabędzki from the Institute of Technology and Life Sciences in Falenty to monitor drought in the Kuyavian region [18, 19]. The advantage of SPI is the fact that it may be determined for various time intervals and climatic conditions. It may provide information for early drought alerts and it may be helpful in assessing the seriousness of the drought [18].

The SWI and SGI indices are determined similarly to the SPI index. SWI refers to the state of surface waters, while SGI refers to groundwater level. The SPI, SWI and SGI indices have been calculated with use of the formula:

$$
X=\frac{f(X)-\mu}{\delta}
$$

where:

$X$ - index (SPI, SWI, and SGI),

$f(X)$ - normalised value of the measured series (precipitation, water level, groundwater level),

$\mu$ - average value of the normalised series,

$\delta$ - standard deviation of the normalised series.

In this study, the $r$ correlation coefficient was used to determine the correlation between the SPI index and the SWI and SGI indices. At the same time, it was assumed that a low value of the coefficient does not mean a lack of correlation between droughts. In the opinion of the author, it rather points to a significant influence of other factors that contribute to the occurrence of drought in surface or groundwaters. However, characterising these factors is not the aim of the present study.

The author also checked the probability with which a negative SPI index indicated the lowering of water level in the water course and in the groundwaters below the median, and vice versa. The probability was calculated with use of two formulas: $H$ [2] (hit-number of events with negative SWI, SGI and SPI values) and $F$ [3] (fails - number of events with negative SPI values and positive SWI, SGI values) [23].

$$
\begin{gathered}
H=\frac{a}{a+c} \\
F=\frac{b}{a+b}
\end{gathered}
$$


where:

$a$ - event with negative SPI, SWI, SGI values,

$b$ - event with negative SPI value and positive SWI, SGI values,

$c-$ event with negative SWI values and positive SGI, SPI values.

\section{Results and discussion}

Correlation coefficients $r$ were determined for time series created from the SPI, SWI and SGI values calculated for different periods. Statistically significant results on $p=0.5$ level were obtained only for the correlation of data concerning hydrological drought and groundwater drought with a meteorological drought index SPI-24.The highest correlations were found between SPI-24 and SWI-6 and SPI-24 and SGI-6. The absolute values of the correlation coefficient increased with the extending accumulation period from 1 to 6 months. For longer accumulation periods, the value of the correlation coefficient decreased (Table 2). This means that long-term meteorological drought has the strongest influence on the occurrence of a seasonal groundwater deficit and lowering the water level in water courses. Thus, no clear correlation between seasonal and mid-term meteorological drought (SPI-6, SPI-12) and drought in surface waters was confirmed. Further studies on the influence of meteorological drought on groundwater and surface water drought should focus on evaluating the correlation between long-term precipitation deficits and seasonal hydrological and hydrogeological drought.

Table 2. Correlation coefficients $r$ between SPI-24 and SWI and SGI in different month scale.

\begin{tabular}{|c|c|c|c|c|c|c|c|c|c|c|}
\hline $\boldsymbol{r}$ & SWI-1 & SWI-3 & SWI-6 & SWI-12 & SWI-24 & SGI-1 & SGI-6 & SGI-6 & SGI-12 & SGI-24 \\
\hline SPI-24 & 0.17 & 0.20 & 0.22 & 0.19 & 0.09 & 0.17 & 0.27 & 0.28 & 0.27 & 0.17 \\
\hline
\end{tabular}

The correlation coefficients between standardised drought indicators calculated for the whole observation period demonstrate a low level of correlation between data. However, this does not mean that different types of drought are not correlated. It demonstrates that further analyses of the influence of meteorological drought on surface and groundwater drought should take into account factors that are independent from precipitation. Particular attention should be paid to the physical properties of land in the vicinity of the observation site, the hydraulic properties of the aquifier and anthropogenic influence [24-26].

The simultaneous courses of meteorological and hydrological drought and of meteorological and groundwater drought determined basing on the SPI, SWI and SGI indices in the most correlated time scales are presented in Fig. 3. In the analysed long-term period several periods with low precipitation and lowered water level were noted (based on the determined, standardised drought indices). Mild and moderate drought was noted from the beginning of the measurement period until 1986 in the groundwater level, and until 1988 in the waters of the Grabowa River. Meteorological drought was also observed from the beginning of the observation period until 1991. Precipitation deficits were also recorded between the years 1992 and 1997 (interrupted: for 3 months in 1995 and 4 months in 1996), later in the years 2000-2001 and 2003-2004. These droughts were not reflected in the measurements of surface water and groundwater levels. The period that deserves particular attention, are the years 2005-2007, when significant precipitation deficits were noted along with a decrease in surface and groundwater levels. One should note the extreme drought indicated by the SWI index in the periods 09.2006-03.2007 and 07.2007-08.2007. A periodical decrease in the SPI and SWI values to negative levels was noted in the years 
2010, 2011 and 2013. In the groundwater levels, the drought continued, on various levels, from 2006 until the end of the observation period.

The calculated probability of positive hits $\mathrm{H}$ for standardised indices in the periods with the highest correlation demonstrated that SPI-24 indicated the occurrence of droughts in surface waters correctly in $69 \%$ of the cases (SWI-6). The F probability indicated the occurrence of a negative SPI- 24 index in $41 \%$ of the cases, while SWI-6 was positive. One may conclude that for groundwater drought, the value of positive hits $\mathrm{H}$ was 0.58 , while false $F$ 0.52. If there are no direct measurement data available for the water level in the water course and groundwater level, the SPI-24 indicator may be used to evaluate the risk of drought. One should take into account the level of probability with which the SPI-24 index indicates the occurrence or lack of drought in surface and groundwaters. It is lower for groundwater drought and higher for surface water drought.

a)

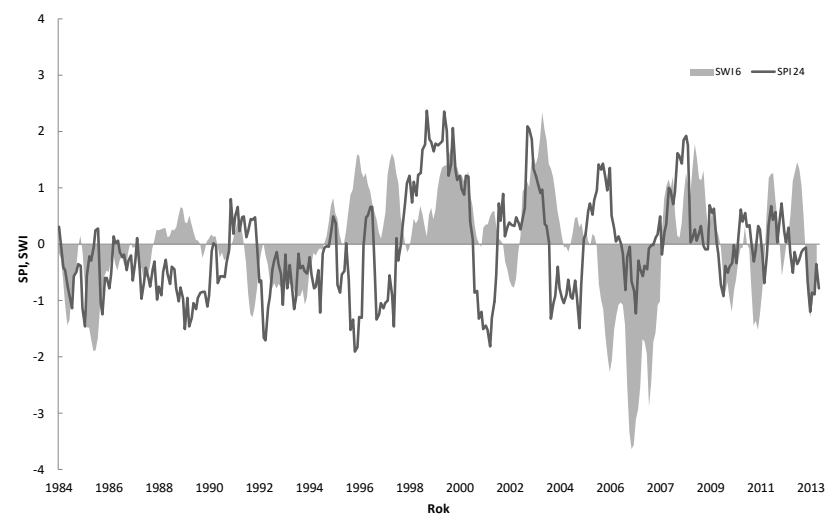

b)

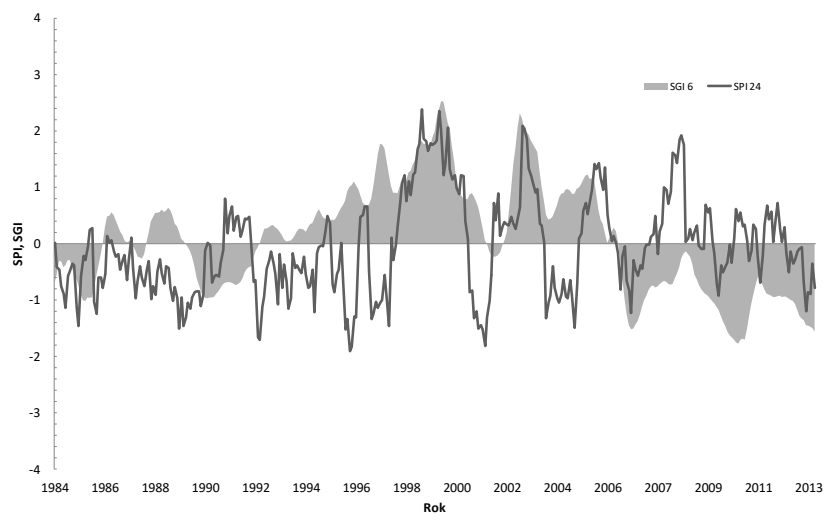

Fig. 3. Plots of SPI-24 vs SWI-6 (a), plots of SPI-24 vs SGI-6 (b).

\section{Conclusions}

1. In order to apply SPI to monitor hydrological and hydrogeological drought, it is required to assess the significance and level of the correlation between drought indices in the test area.

2. Due to similar calculation methodology, standardised SPI, SWI and SGI indices allow for the analysis of correlations between meteoroidal, hydrological and groundwater drought. One cannot assume unconditionally that the SPI calculated for a period of 
6-12 months correlates best with the flow intensity in rivers and from a 24-month period with the groundwater level. The evaluation of correlation between droughts of various duration must be preceded by a statistical significance analysis.

3. The analyses have demonstrated that the highest statistically significant correlations exit between SPI-24 and SWI-6 in the observation and measurement site Krąg on the Grabowa River and between SPI-24 and SGI-6 in the observation and measurement site for groundwater in Polanów. The relatively low level of the correlation coefficient $r$ between the SPI drought index and the SWI and SGI indices does not mean a lack of correlation. It is merely information that droughts in surface and groundwaters are influenced by factors other than precipitation deficit. Further analyses of the possibilities to apply the SPI index to monitor hydrological and hydrogeological drought should involve a detailed characteristics of the natural conditions and obtaining knowledge about the analysed are in order to select the factors that influence the correlation level.

4. In the presented example, the probability of correct determination of hydrological drought with use of the SPI-24 index in the observation and measurement site Krag on the Grabowa River was estimated at $69 \%$, and at $58 \%$ in the groundwater observation and measurement site in Polanów. These are low values.

5. The analyses presented in this paper are preliminary. They constitute a basis for further research that will enable the monitoring of hydrological drought in surface and groundwaters based on the standardised SPI index.

The works were conducted as part of own research of the Institute of Environmental Engineering of the Wrocław University of Environmental and Life Sciences No. B030/0102/17, from the funds for statutory operations from MNiSW.

\section{References}

1. D.S. Arndt, M.O. Baringer, M. Johnson, Bull. Amer. Meteorol. Soc. 91, 7, S1 (2011)

2. A. Boczoń, A. Kowalska, M. Dudzińska, M. Wróbel, Pol. J. Environ. Stud. 25, 5 (2016)

3. E.J. Burke, S.J. Brown, N. Christidis, J. Hydrometeorol. 75, 1113 (2006)

4. A. Bartczak, R. Glazik, S. Tyszkowski, Sci. Nat. Technol. 84, 46 (2014)

5. L. Łabędzki, B. Bąk, Woda-Środowisko-Obszary Wiejskie 42a, 111 (2004)

6. T.B. McKee, N.J. Doesken, J. Kleist, Proc. Conf. Appl. Climatol. 17, 22, 179 (1993)

7. C. Bhuiyan, XXth ISPRS Congress, 12 (1994)

8. R.N. Sahoo, D. Dutta, M. Khanna, N. Kumar, S.K. Bandyopadhyay, Nat. Hazards 772, 733 (2015).

9. C. Bhuiyan, R.P.Singh, F.N. Kogan, Int. J. Appl. Earth Obs. Geoinf. 84, 289 (2006)

10. J.P. Bloomfield, B.P. Marchant, Hydrol. Earth Syst. Sci. 17, 4769 (2013)

11. www.kzgw.gov.pl

12. M. Stolarska, J.P. Gurwin, Wskazanie obszarów występowania zjawiska suszy wraz $z$ określeniem jej zasięgu i natężenia na terenie $R Z G W w$ Warszawie oraz analiza możliwości zwiększenia na wskazanych obszarach dyspozycyjności zasobów wodnych (Wind-hydro, Łódź, 2014)

13. J. Gurwin, Episodes 37, 3, 172 (2014)

14. J. Kondracki, Geografia regionalna Polski (Wyd. Nauk. PWN, Warszawa, 2001) 
15. Raport-przygotowanie-danych-hydrologicznych, app. 1, www.isok.gov.pl/dane/web_articles_files/2783/zal-1-raport-przygotowanie-danychhydrologicznych.pdf.

16. B. Bąk, L. Łabedzki, J. Water Land Dev. 6 (2002)

17. L. Łabędzki, B. Bąk, E. Kanecka-Geszke, W. Kasperska-Wołowicz, K. Smarzyńska, Środowisko-Obszary Wiejskie. Rozprawy Naukowe i Monografie, 25 (2008)

18. L. Łabedzki, B. Bak, Infrastruct. Ecol. Rural Areas, 2/I (2013)

19. T. Tokarczyk, Infrastruct. Ecol. Rural Areas, 7 (2008)

20. agrometeo.itp.edu.pl

21. L. Vermes, Guidelines for Water Management 309, 29 (1998)

22. J.L. Musuuza, A.F. Van Loon, A.J. Teuling, Hydrol. Earth Syst. Sci. 203, 1117 (2016)

23. M. Mohammadi-Ghaleni, K. Ebrahimi, 21st Int. Congr. Irrig. Drain. 15 (2011)

24. D.S. Willks, Statistical Methods in the Atmospheric Sciences (Academic Press, 2011)

25. Z. Chen, S.E. Grasby, K.G. Osadetz, J. Hydrol. 2601, 102 (2002)

26. D.O. Whittemore, J.J. Butler Jr, B.B. Wilson, Hydrol. Sci. J 611, 134 (2016) 